\title{
Genetic Coefficient and Validation of DSSAT Model for Cotton under Different Growing Environments
}

\author{
Sagar Kumar*, Ram Niwas, M.L. Khichar, Amit Singh, Premdeep, \\ Yogesh Kumar and Abhilash
}
Department of Agricultural Meteorology, College of Agriculture (COA), CCS Haryana Agricultural University, Hisar-125004, Haryana, India
*Corresponding author

\begin{tabular}{|c|c|}
\hline & A B S T R A C T \\
\hline $\begin{array}{l}\text { Cotton, growing } \\
\text { environment, } \\
\text { DSSAT, genetic } \\
\text { coefficient and } \\
\text { validation. }\end{array}$ & \multirow{3}{*}{$\begin{array}{l}\text { The field experiment was conducted at the research area of the Department of Agricultural } \\
\text { Meteorology, CCS Haryana Agricultural University, Hisar, during the kharif season of } 2015- \\
\text { 16. The main plots treatments consisted of three date of sowing } 2^{\text {nd }} \text { week of May (D1), } 3^{\text {rd }} \\
\text { week of May (D2) and } 1^{\text {st }} \text { week of June (D3) and sub-plots consisted of three varieties } \\
\text { (Pancham 541, SP 7121 and RCH 791. Genetic coefficient for DSSAT- CROPGRO model } \\
\text { such as EM-FL, FL-SH, SD-PM, FL-LF, SLAVR, SIZLF, XFRT, SDPRO, SDLIP, } \\
\text { SFDUR, THRSH, SDPDV, CSDL, PP-SEN, LFMAX, WTPSD and PO-DUR were } \\
\text { evaluated. SLAVR, XFRT and THRSH were main coefficients which influenced LAI and } \\
\text { seed cotton yield. The model performance in respect of phenology was good with error of } \\
\pm 5 \% \text { for all the three cotton cultivars and growing environments. Also the model } \\
\text { performance was within acceptable range of } \pm 10.0 \% \text { for LAI, seed cotton yield and } \\
\text { biomass for all the cultivars and growing environments. But the model performance was } \\
\text { not within acceptable range for the crop sown in } 1^{\text {st }} \text { week of June. }\end{array}$} \\
\hline Article Info & \\
\hline $\begin{array}{l}\text { Accepted: } \\
12 \text { March } \\
\text { Available } \\
10 \text { April } 2\end{array}$ & \\
\hline
\end{tabular}

\section{Introduction}

The Decision Support System for Agrotechnology Transfer (DSSAT) is the major product of the IBSNAT (International Benchmark Site Network for Agrotechnology Transfer) project, initiated in 1982 (Uehara and Tsuji, 1998). Although this project ended in 1993, its developers have expanded since then and continue to update and maintain this software under the auspices of ICASA. The central components of the DSSAT software are crop simulation models and programs to facilitate their application in different regions of the world. It is the quantitative tool based on scientific knowledge that can evaluate the effect of climatic, edaphic, hydrological and agronomic factors on crop growth and yield. The decision support system for agrotechnology transfer (DSSAT) has been in use for the last 15 years by researchers worldwide (Hoogenboom et al., 2012; Jones et al., 2003). This package incorporates models of 28 different crops with software that facilitates the evaluation and application of the crop models for different purposes.

DSSAT was developed to assess yield, resource use and risk associated with different crop production practices (Tsuji et al., 1994). The system DSSAT (Tsuji et al., 1994) is an example of a management tool that enables 
farmers to match the biological requirement of a crop to the physical characteristics of the land and ambient air to attain specified objectives. DSSAT software could help the decision makers to implement future agriculture strategies under different scenarios related to agriculture practices with the use of measured site - specific pedological, physiological, agronomical and meteorological data (Hoogenboom et al., 1994).

The study of impact of climate change on crops needs simulation model, as it provide a means to quantify the effects of climate, soil and management on crop growth, productivity and sustainability of agricultural production. These tools can reduce the expensive and time consuming field experimentation as they can be used to extrapolate the results of research conducted in one season or location to other season, location, or management (Boomiraj et al., 2007).

\section{Materials and Methods}

The field experiment was conducted at the research area of the Department of Agricultural Meteorology, CCS Haryana Agricultural University, Hisar, during the kharif season of 2015-16. The main plots treatments consisted of three date of sowing and the sub-plots consisted of three varieties. The twenty seven treatment combinations were tested in random block design with three replications.

Plant height was measured at important phenophases on three tagged plants in each plot. The height was measured from the rootshoot junction to the apical point with a wooden meter scale and mean values were calculated.

Three plants were uprooted from each plot and their leaves were used for measuring leaf area per plant $\left(\mathrm{cm}^{2}\right)$ with the help of leaf area meter (LI-3000 Leaf Area Meter, LICOR Ltd., Nebraska, USA) at 30, 60, 90, 120 and 150 days after sowing. These samples were oven dried and weighted for dry biomass calculation on hectare basis. Yield, yield attributes and yield quality were recorded at harvest.

\section{Input data for CROPGRO-Cotton model}

'CROPGRO-Cotton' is a physiological based dynamic crop growth simulation model which is responsive to daily weather inputs. The minimum data required for running CROPGRO-Cotton are given in table 1.

Inputs required for creating a new soil profile for DSSAT Crop Model

\section{General Information}

\begin{tabular}{|l|l|}
\hline 1. Country: INDIA & 2. Site Name: CCSHAU, HISAR \\
\hline 3. Latitude: $29^{\circ} 10^{\prime}$ & 4. Longitude: $75^{\circ} 46^{\prime}$ \\
\hline 5. Soil Data source: NBSS & 6. Soil Series name: NINDANA \\
\hline 7. Soil Classification: Typic ustochrept & \\
\hline
\end{tabular}

II. Surface Information

1. Colour

2. Drainage

3. \% slope

(a) Brown

4. Runoff potential

5. Fertility factor (0 to 1) ONE
6. Runoff Curve Number

\section{Albedo}

8. Drainage rate

III. Layer-wise soil information: No. of layers depends on the location. Here layers up to $120 \mathrm{~cm}$ depth (Table 2). 


\section{Calibration of the model}

Calibration of model involves computing and adjusting certain model parameters or relationships to make the model work for any desired location. When using a crop model, one has to estimate the cultivar characteristics if they have not been previously determined. The model requires twenty cultivar specific genetic coefficients. These genetic coefficients were computed as per details given below:

\section{Parameters Description of parameters}

EXPON Number of experiment used to estimate cultivar parameters

ECO\# $\quad$ Code for the ecotype to which this cultivar belongs

CSDL Critical Short Day Length below which reproductive development progresses with no day length effect (for short day plants) (hour)

PPSEN Slope of the relative response of development to photoperiod with time (Positive for short day plants) (1/hour)

EM-FL Time between plant emergence and flower appearance (R1) (photothermal days)

FL-SH Time between first flower and first pod (R3) (photothermal days)

FL-SD Time between first flower and first seed (R5) (photothermal days)

SD-PM Time between first seed (R5) and physiological maturity (R7) (photothermal days)

FL-LF Time between first flower (R1) and end of leaf expansion (photothermal days)

LFMAX Maximum leaf photosynthesis rate at $30^{\circ} \mathrm{C}, 350 \mathrm{vpm} \mathrm{CO}_{2}$ and high light (mg $\mathrm{CO}_{2} / \mathrm{m}^{2}$-s) ---from Reddy Adv. Agron. 1997?

SLAVR Specific leaf area of cultivar under standard growth conditions $\left(\mathrm{cm}^{2} / \mathrm{g}\right)$

SIZLE Maximum size of full leaf (three leaflets) $\left(\mathrm{cm}^{2}\right)$

XFRT Maximum fraction of daily growth that is partitioned to seed+shell

WTPSD Maximum weight per seed $(\mathrm{g})$

SFDUR Seed filling duration for pod cohort at standard growth conditions (photothermal days)

SDPDV Average seed per pod under standard growing conditions (\#/pod)

PODUR Time required for cultivar to reach final pod load under optimal conditions (photothermal days)

THRSH Threshing percentage. The maxi. ratio of seed [seed/(seed+shell)]

SDPRO Fraction protein in seeds $[\mathrm{g}$ (protein) $/ \mathrm{g}$ (seed)]

SDLIP Fraction oil in seed $[\mathrm{g}($ oil $) / \mathrm{g}(\mathrm{seed})]$

The model was run and validated by comparing the predicted output with observed parameters. Deviation of predicted value from observed were calculated and error of the model to predict different crop parameters was quantified using the methods given below:

$$
\mathrm{MAE}=\sum_{\mathrm{i}=1}^{\mathrm{n}}\left[1 \mathrm{P}_{\mathrm{i}}-\mathrm{O}_{\mathrm{i}} 1\right] / \mathrm{n}
$$

$$
\begin{aligned}
& \mathrm{MBE}=\sum_{\mathrm{i}-1}^{\mathrm{n}}\left[\mathrm{P}_{\mathrm{i}}-\mathrm{O}_{\mathrm{i}}\right] / \mathrm{n} \\
& \mathrm{RMSE}=\left[\sum_{\mathrm{i}=1}^{\mathrm{n}}\left(\mathrm{P}_{\mathrm{i}}-\mathrm{O}_{\mathrm{i}}\right)^{2} / \mathrm{n}\right]^{1 / 2} \\
& \mathrm{PE}=\{(\mathrm{P}-\mathrm{O}) / \mathrm{O}\} * 100
\end{aligned}
$$

Where, $\mathrm{O}=$ observed, $\mathrm{P}=$ simulated. 


\section{Results and Discussion}

The genetic coefficients were evaluated and the model was validated for different sowing environment with different cultivars: Pancham 541, SP 7121 and RCH 791. DSSAT model was calibrated by different data sets on phenology, leaf area index, bolls weight/plant, biomass and seed cotton yield for the evaluation of genetic coefficients.

\section{Genetic coefficients}

The core coefficients such as maximum threshing percentage was calculated and observed in RCH 791(91\%) followed by SP 7121(79\%) and Pancham 541(74\%) sown in table 3. The value of CSDL, PP-SEN, LFMAX and WTPSD used as default, the value of EM-FL, FL-SH, SD-PM, FL-LF, SLAVR, SIZLF, XFRT, SDPRO and SDLIP was computed and they are maximum in cotton cultivar RCH 791 followed by SP 7121 and Pancham 541. SFDUR, SDPDV and PODUR were computed and found equal in SP 7121 and Pancham 541 and maximum in RCH 791. SLAVR, XFRT and THRSH have maximum influence on LAI and seed cotton yield. Ortiz et al., (2009) also reported the values for most of the vegetative and reproductive cultivar coefficients were higher than those from the other commercial cotton cultivars that are part of the DSSAT data-base, suggesting that the cultivar grown in this experiment required more days to the beginning of the reproductive phase.

\section{Validation}

\section{Days to flowering}

The observed mean values of days to flowering for three cotton cv. Pancham 541, SP 7121 and RCH 791 were 70,72 and 74, whereas the model simulated 70,72 and 72 days, resp. (Table 4). The percent error was observed lower for cv. SP 7121 (0.0) followed by Pancham 541 (0.0) and RCH 791 (-3.3). Similarly, the percent error was observed lower for $3^{\text {rd }}$ week of May (D2) followed by $1^{\text {st }}$ week of June (D3) and $2^{\text {nd }}$ week of May (D1). This clearly showed that model performance was found to be good for all the three cotton cultivars and for all the growing environments for simulation of days to flowering as percent error was $< \pm$ 5. Ortiz et al., (2009) also showed the difference between observed and simulated values for the flowering and physiological maturity dates over the control treatment was two days.

\section{Days to maturity}

Pancham 541, SP 7121 and RCH 791 matured in 136, 138 and 141 days, while model simulated 137, 139 and 142 days, respectively as sown in table 5. SP 7121 performed better and the model percent error was observed lower for $3^{\text {rd }}$ week of May (D2) overestimated the days to maturity. The percent error was over estimated by the model or error was negligible. The simulation performance of the model in respect of days taken to maturity was found to be the best as error was $<1.0 \%$. Also, the results of phenological stages of maize simulated by InfoCrop model are supported by Singh et al., (1994), Akula (2003) and Soler et al., (2007).

\section{Growth and yield parameters}

\section{Maximum LAI}

LAI of Pancham 541, SP 7121 and RCH 791 were $2.9,3.1$ and 3.5 , while model simulated LAI were $3.1,3.4$ and 3.6, respectively as sown in table 6 . The percent error was ranged between -9.6 and $19.4 \%$. The performance of model was not in acceptable range in $3^{\text {rd }}$ date of sowing (D3). 
Table.1 List of input required by CROPGRO-Cotton model

\begin{tabular}{|c|c|c|}
\hline Input variables & Acronym & Units \\
\hline \multicolumn{3}{|l|}{ Site data } \\
\hline Latitude & LAT & Degree \\
\hline Longitude & LONG & Degree \\
\hline Elevation & ELEV & $\mathrm{M}$ \\
\hline Average air temperature & TAV & ${ }^{\circ} \mathrm{C}$ \\
\hline Height of temperature measurement & TMHT & $\mathrm{M}$ \\
\hline Height of wind measurement & WMHT & $\mathrm{M}$ \\
\hline $\mathrm{CO}_{2}$ concentration & & ppm \\
\hline \multicolumn{3}{|l|}{ Daily weather data } \\
\hline Maximum temperature & TEMPMAX & ${ }^{\circ} \mathrm{C}$ \\
\hline Minimum temperature & TEMPMIN & ${ }^{\circ} \mathrm{C}$ \\
\hline Rainfall & RAIN & $\mathrm{Mm}$ \\
\hline Sun Shine hours & SSH & hours \\
\hline \multicolumn{3}{|l|}{ Soil characteristics } \\
\hline Soil texture & SLTX & \\
\hline Soil local classification & SLDESC & \\
\hline Soil family SCS system & TACON & \\
\hline Soil depth & SLDP & $\mathrm{M}$ \\
\hline Colour, moist & SCOM & \\
\hline Albedo (fraction) & SALB & Fraction \\
\hline Evaporation limit & $\mathrm{U}$ & $\mathrm{Cm}$ \\
\hline Drainage rate (fraction day ${ }^{-1}$ ) & SWCON & $\underset{1}{\text { Fraction day }}$ \\
\hline Runoff curve number & $\mathrm{CN} 2$ & \\
\hline Mineralization (0 to 1 scale) & SLNF & \\
\hline Photosynthesis factor (0 to 1 scale) & SLPE & \\
\hline $\mathrm{pH}$ in buffer determination method & SMPX & \\
\hline Potassium determination method & SMKE & \\
\hline \multicolumn{3}{|l|}{ Horizon-wise } \\
\hline Lower limit drained & LL(L) & $\mathrm{cm}^{3} \mathrm{~cm}^{3}$ \\
\hline Upper limit drained & DUL(L) & $\mathrm{cm}^{3} \mathrm{~cm}^{3}$ \\
\hline Upper limit drained & SAT(L) & $\mathrm{cm}^{3} \mathrm{~cm}^{3}$ \\
\hline Saturated hydraulic conductivity & SWCN(L) & $\mathrm{cmhr}^{-1}$ \\
\hline Bulk density moist & $\mathrm{BD}(\mathrm{L})$ & $\mathrm{gcm}^{-3}$ \\
\hline Organic carbon & $\mathrm{OC}(\mathrm{L})$ & $\%$ \\
\hline Clay $(<0.002 \mathrm{~mm})^{-}$ & CLAY(L) & $\%$ \\
\hline Silt( $(0.05$ to $0.002 \mathrm{~mm})$ & SILT(L) & $\%$ \\
\hline
\end{tabular}




\begin{tabular}{|c|c|c|}
\hline Input variables & Acronym & Units \\
\hline Coarse fraction (>2 mm) & STONES(L) & $\%$ \\
\hline Total nitrogen & TOTN(L) & $\%$ \\
\hline $\mathrm{pH}$ in buffer & PHKCL(L) & \\
\hline Cation exchange capacity & CEC(L) & $\mathrm{Cmolkg}^{-1}$ \\
\hline Root growth factor 0 to 1 & SHF(L) & \\
\hline \multicolumn{3}{|l|}{ Management data } \\
\hline Sowing date & YRPLT & \\
\hline Emergence date & IEMERG & \\
\hline Plant population at seedling & PLNATS & Plantm $^{-2}$ \\
\hline Planting method (TP/direct seeded) & PLME & \\
\hline $\begin{array}{l}\text { Planting distribution } \\
\text { (row/broadcast/hill) }\end{array}$ & PLDS & \\
\hline Row spacing & ROWSPS & $\mathrm{Cm}$ \\
\hline Row direction (degree from north) & AZIR & \\
\hline Plants per hill & PLPH & \\
\hline Seed rate & SDWTRL & kgha $^{-1}$ \\
\hline Sowing depth & SDEPTH & $\mathrm{Cm}$ \\
\hline Irrigation dates & IDLAPL $(\mathrm{J})$ & \\
\hline Irrigation amount & AMT(J) & $\mathrm{Mm}$ \\
\hline Method of irrigation & IRRCOD $(\mathrm{J})$ & \\
\hline Fertilizer application dates & FDAY $(J)$ & \\
\hline Fertilizer amount $\mathrm{N}$ & ANFER(J) & kgha $^{-1}$ \\
\hline Fertilizer type & IFTYPE(J) & \\
\hline Fertilizer application method & FERCOD(J) & \\
\hline Fertilizer incorporation depth & DFERT(J) & $\mathrm{Cm}$ \\
\hline Tillage date & TDATE(J) & \\
\hline Tillage implement & TIMPL(J) & \\
\hline Tillage depth & TDEP(J) & $\mathrm{Cm}$ \\
\hline Residue management & LNRES & \\
\hline Chemical applications & LNCHE & \\
\hline Environment modification & LNENV & \\
\hline \multicolumn{3}{|l|}{ Harvest details } \\
\hline Harvest & HDATE(J) & \\
\hline Harvest stage & HSTG(J) & \\
\hline Harvest component & $\operatorname{HCOM}(\mathrm{J})$ & \\
\hline Harvest percentage & $\mathrm{kg} \mathrm{ha}^{-1}$ & $\%$ \\
\hline
\end{tabular}


Table.2 Layer- wise soil information for input of DSSAT model

\begin{tabular}{|c|c|c|c|c|c|c|c|}
\hline $\begin{array}{l}\text { Depth } \\
\text { (bottom) } \\
\text { Cm }\end{array}$ & $\begin{array}{c}\text { Master } \\
\text { Horizon }\end{array}$ & $\begin{array}{c}\text { Clay } \\
\text { \% }\end{array}$ & $\begin{array}{c}\text { Silt } \\
\text { \% }\end{array}$ & $\begin{array}{c}\text { Stones } \\
\text { \% }\end{array}$ & $\begin{array}{c}\text { Organic } \\
\text { Carbon } \\
\%\end{array}$ & $\begin{array}{c}\text { pH in } \\
\text { water }\end{array}$ & $\begin{array}{c}\text { Cation } \\
\text { Exchange } \\
\text { Capacity } \\
\text { C mol/kg }\end{array}$ \\
\hline 5 & AP & 10.7 & 22.3 & -99 & 0.41 & 8.1 & 11.4 \\
\hline 29 & A1 & 13.4 & 25.0 & -99 & 0.26 & 8.4 & 12.4 \\
\hline 57 & B2 & 14.3 & 26.2 & -99 & 0.26 & 8.3 & 13.4 \\
\hline 80 & B2 & 16.0 & 27.9 & -99 & 0.23 & 8.3 & 17.4 \\
\hline 103 & B2 & 16.5 & 28.3 & -99 & 0.22 & 8.2 & 17.7 \\
\hline 127 & B3 & 16.9 & 28.7 & -99 & 0.20 & 8.3 & 19.5 \\
\hline
\end{tabular}

\begin{tabular}{|c|c|c|c|c|c|c|}
\hline $\begin{array}{c}\text { Depth } \\
\text { (bottom) } \\
\mathbf{C m}\end{array}$ & $\begin{array}{c}\text { Lower } \\
\text { limit }\end{array}$ & $\begin{array}{c}\text { Drainage } \\
\text { Upper } \\
\text { Limit }\end{array}$ & Saturation & $\begin{array}{c}\text { Bulk } \\
\text { Density } \\
\text { g/cm3 }\end{array}$ & $\begin{array}{c}\text { Saturated } \\
\text { Hydraulic } \\
\text { Conductivity Cm/hr }\end{array}$ & $\begin{array}{c}\text { Root growth } \\
\text { Factor 0.0-1.0 }\end{array}$ \\
\hline 15 & 0.091 & 0.183 & 0.412 & 1.49 & 2.59 & 1.00 \\
\hline 29 & 0.100 & 0.196 & 0.407 & 1.59 & 2.59 & 0.644 \\
\hline 57 & 0.105 & 0.203 & 0.410 & 1.50 & 2.59 & 0.423 \\
\hline 80 & 0.112 & 0.215 & 0.410 & 1.50 & 2.59 & 0.254 \\
\hline 103 & 0.114 & 0.218 & 0.410 & 1.50 & 2.59 & 0.160 \\
\hline 127 & 0.116 & 0.220 & 0.411 & 1.50 & 2.59 & 0.100 \\
\hline
\end{tabular}

Table.3 Genetic coefficient of cotton cultivar evaluated under different growing environments

\begin{tabular}{|l|c|c|c|c|c|c|c|c|c|c|}
\hline VARITIES & CSDL & $\begin{array}{c}\text { PP- } \\
\text { SEN }\end{array}$ & $\begin{array}{c}\text { EM- } \\
\text { FL }\end{array}$ & $\begin{array}{c}\text { FL- } \\
\text { SH }\end{array}$ & $\begin{array}{c}\text { FL- } \\
\text { SD }\end{array}$ & $\begin{array}{c}\text { SD- } \\
\text { PM }\end{array}$ & $\begin{array}{c}\text { FL- } \\
\text { LF }\end{array}$ & $\begin{array}{c}\text { LF } \\
\text { MAX }\end{array}$ & SLAVR & SIZLF \\
\hline SP 7121 & 23 & 0.01 & 42 & 13 & 18 & 55 & 70 & 1.3 & 390 & 390 \\
\hline $\begin{array}{l}\text { PANCHAM } \\
\text { 541 }\end{array}$ & 23 & 0.01 & 40 & 11 & 16 & 54 & 68 & 1.3 & 380 & 380 \\
\hline RCH 791 & 23 & 0.01 & 46 & 14 & 19 & 56 & 75 & 1.3 & 420 & 410 \\
\hline
\end{tabular}

\begin{tabular}{|l|c|l|c|c|c|c|c|c|}
\hline VARITIES & XFRT & WTPSD & SFDUR & SDPDV & $\begin{array}{c}\text { PO- } \\
\text { DUR }\end{array}$ & THRSH & $\begin{array}{c}\text { SD } \\
\text { PRO }\end{array}$ & SDLIP \\
\hline SP 7121 & 0.75 & 0.18 & 35 & 27 & 10 & 79 & 0.141 & 0.12 \\
\hline $\begin{array}{l}\text { PANCHAM } \\
\text { 541 }\end{array}$ & 0.65 & 0.18 & 35 & 27 & 10 & 74 & 0.153 & 0.10 \\
\hline RCH 791 & 0.91 & 0.18 & 40 & 30 & 12 & 91 & 0.145 & 0.13 \\
\hline
\end{tabular}


Table.4 Test criteria of cotton phenology (Days to Flowering) using DSSAT model during 2015-16

\begin{tabular}{|l|c|c|c|c|c|c|}
\hline \multicolumn{7}{|c|}{ Days to Flowering } \\
\hline & O & S & PE & RMSE & MBE & MAE \\
\hline D1(12MAY) & 72 & 73 & -1.4 & 1.7 & 1.0 & 1.0 \\
\hline D2(21MAY) & 72 & 73 & -0.9 & 1.2 & 0.7 & 0.7 \\
\hline D3(3JUNE) & 69 & 70 & -1.0 & 1.2 & 0.7 & 0.7 \\
\hline Pancham 541 & 70 & 70 & 0.0 & 0.0 & 0.0 & 0.0 \\
\hline SP 7121 & 72 & 72 & 0.0 & 0.0 & 0.0 & 0.0 \\
\hline RCH 791 & 72 & 74 & -3.3 & 2.4 & 2.3 & 2.3 \\
\hline
\end{tabular}

Where: O:- Observed, S:- Simulated, E(\%):- Error \%, RMSE:- Root mean square error,MBE:- mean bias error, MAE:- mean absolute error

Table.5 Test criteria of cotton phenology (Days to physiological maturity) using DSSAT model in 2015-16

\begin{tabular}{|l|c|c|c|c|c|c|}
\hline \multicolumn{7}{|c|}{ Days to Physiological maturity } \\
\hline & O & S & PE & RMSE & MBE & MAE \\
\hline D1(12MAY) & 139 & 139 & 0.0 & 0.0 & 0.0 & 0.0 \\
\hline D2(21MAY) & 140 & 139 & 0.2 & 0.6 & -0.3 & 0.3 \\
\hline D3(3JUNE) & 138 & 137 & 0.7 & 1.0 & -1.0 & 1.0 \\
\hline Pancham 541 & 137 & 136 & 0.2 & 0.6 & -0.3 & 0.3 \\
\hline SP 7121 & 139 & 138 & 0.2 & 0.6 & -0.3 & 0.3 \\
\hline RCH 791 & 142 & 141 & 0.5 & 0.8 & -0.7 & 0.7 \\
\hline
\end{tabular}

Table.6 Test criteria of maximum LAI and bolls wt./plant using DSSAT model during 2015-16

\begin{tabular}{|l|c|c|c|c|c|c|}
\hline \multicolumn{7}{|c|}{ Maximum LAI } \\
\hline & O & S & PE & RMSE & MBE & MAE \\
\hline D1(12MAY) & 3.5 & 3.6 & 4.5 & 0.3 & -0.2 & 0.3 \\
\hline D2(21MAY) & 2.7 & 2.5 & -9.6 & 0.3 & 0.3 & 0.3 \\
\hline D3(3JUNE) & 3.3 & 4.0 & 19.4 & 0.7 & -0.6 & 0.6 \\
\hline Pancham 541 & 2.9 & 3.1 & 6.8 & 0.5 & -0.2 & 0.5 \\
\hline SP 7121 & 3.1 & 3.4 & 7.7 & 0.5 & -0.2 & 0.4 \\
\hline RCH 791 & 3.5 & 3.6 & 2.7 & 0.3 & -0.1 & 0.3 \\
\hline \multicolumn{7}{|c|}{ Bolls Weight / Plant } \\
\hline D1(12MAY) & 27.7 & 25.9 & -6.7 & 2.1 & -1.9 & MAE \\
\hline D2(21MAY) & 19.7 & 18.1 & -7.7 & 1.6 & -1.5 & 1.9 \\
\hline D3(3JUNE) & 10.8 & 9.6 & -11.8 & 1.4 & -1.3 & 1.3 \\
\hline Pancham 541 & 17.7 & 16.2 & -8.3 & 1.5 & -1.5 & 1.5 \\
\hline SP 7121 & 19.3 & 18.0 & -7.0 & 1.4 & -1.3 & 1.3 \\
\hline RCH 791 & 21.2 & 19.4 & -8.7 & 2.1 & -1.9 & 1.9 \\
\hline
\end{tabular}


Table.7 Test criteria of Biomass and Seed cotton yield using DSSAT model during 2015-16

\begin{tabular}{|c|c|c|c|c|c|c|}
\hline \multicolumn{7}{|c|}{ Biomass (q/ha) } \\
\hline & $\mathbf{O}$ & $\mathbf{S}$ & PE & RMSE & MBE & MAE \\
\hline D1(12MAY) & 36.3 & 37.8 & 4.1 & 3.3 & 1.5 & 3.1 \\
\hline D2(21MAY) & 28.1 & 29.2 & 4.0 & 2.3 & 1.1 & 1.9 \\
\hline D3(3JUNE) & 20.9 & 17.3 & -17.4 & 3.7 & -3.6 & 3.6 \\
\hline Pancham 541 & 24.9 & 26.8 & 7.4 & 3.8 & 1.8 & 3.7 \\
\hline SP 7121 & 28.6 & 28.4 & -0.5 & 2.4 & -0.1 & 2.1 \\
\hline RCH 791 & 31.8 & 29.1 & -8.5 & 3.1 & -2.7 & 2.7 \\
\hline \multicolumn{7}{|c|}{ Seed cotton yield (q/ha) } \\
\hline & $\mathbf{O}$ & $\mathbf{S}$ & $\mathbf{P E}$ & RMSE & MBE & MAE \\
\hline D1(12MAY) & 17.7 & 19.3 & 9.0 & 1.7 & -1.6 & 1.6 \\
\hline D2(21MAY) & 14.8 & 14.2 & -4.0 & 2.1 & 0.6 & 1.7 \\
\hline D3(3JUNE) & 10.1 & 8.3 & -17.6 & 2.1 & 1.8 & 1.8 \\
\hline Pancham 541 & 11.3 & 11.5 & 2.5 & 0.8 & -0.3 & 0.7 \\
\hline SP 7121 & 13.2 & 13.6 & 3.2 & 1.4 & -0.4 & 1.4 \\
\hline RCH 791 & 18.2 & 16.7 & -8.2 & 3.0 & 1.5 & 3.0 \\
\hline
\end{tabular}

The evaluation of the model on an overall basis revealed that the simulation performance of the model in respect of LAI was found good with an accepted level $( \pm 10.0 \%)$ for $1^{\text {st }}$ and $2^{\text {nd }}$ date of sowing and all the three cultivars. Ortiz et al., (2009) reported that model under predicted maximum LAI for all fumigated treatments. The evaluation of the model on an overall performance of simulation was good.

\section{Bolls weight/plant}

Bolls weight/plant obtained for $\mathrm{cv}$. Pancham 541, SP 7121 and RCH 791 were 17.7, 19.3 and $21.2 \mathrm{~g}$, while model simulated 16.2, 18.0 and $19.4 \mathrm{~g}$, respectively as shown in table 6 . The average percent error was 8.7 ( $\mathrm{RCH} 791)$. The model underestimated bolls weight/plant in all the three growing environments and in all the three cotton cultivars. The overall performance of simulation was found good within accepted level $( \pm 10 \%)$ for cotton. Ortiz et al., (2009) also reported the changes in boll weight accumulation throughout the season and the final boll weight at harvest were fairly well predicted by the CSM-CROPGROCotton model.

\section{Biomass}

The biomass yield of RCH 791and SP 7121 was underestimated and of Pancham 541 overestimated by the model (Table 7). The average percent error for biomass yield was found 8.5(RCH 791), 0.5 (SP 7121) and 7.4 $\%$ (Pancham 541). The average percent error was 4.1(D1), 4.0(D2) and 17.4(D3). The biomass yield simulation was found good $( \pm 10.0 \%)$ for cotton for all cultivars and $1^{\text {st }}$ and $2^{\text {nd }}$ date of sowing, except $3^{\text {rd }}$ date of sowing. Ortiz et al., (2009) also reported that calibrated coefficients improved the total biomass and boll weight predictions by $14.3 \%$ and $6.1 \%$, respectively, when compared to the original default values.

\section{Seed cotton yield}

The seed cotton yield observed in field experiment for cv. Pancham 541, SP 7121 and RCH 791 were 18.2, 13.2 and $11.3 \mathrm{q} /$ ha while 
model simulated yield was16.7, 13.6 and 11.5 $\mathrm{q} /$ ha, respectively (Table 7 ). The average percent error was within acceptable error limit in all the treatment except $1^{\text {st }}$ week of June (D3) which was not within acceptable limit of the model. This shows that the evaluation of the model on an overall basis revealed that the simulated yield was good with an accepted level of percent error for cotton except $1^{\text {st }}$ week of June (D3) sown crop. Also, these results are supported by finding of Soler et al., (2007) for maize and Singh et al., (1994) for groundnut yield and yield attributes simulated by PNUTGROW model.

In conclusion, genetic coefficients were evaluated and DSSAT Model was validated for cotton cultivars: Pancham 541, SP 7121 and $\mathrm{RCH}$ 791. The model performance in respect of phenology was found to be good for all the three cotton cultivars and for all the growing environments. Also the model performance was good for all the cultivars, $2^{\text {nd }}$ and $3^{\text {rd }}$ week of May sown crop in case of seed cotton yield, biomass and maximum LAI. But the model performance was not good for the crop sown in $1^{\text {st }}$ week of June.

\section{References}

Akula, B. 2003.Ph.D thesis, Anand Agricultural University, Gujarat.

Boomiraj, K., Chakrabarti, B., Aggarwal, P.K., Choudhary, R. and Chander, S. 2007. Impact of Climate Change on Indian mustard (Brassica juncea) in contrasting Agro-environments of the tropics.ISPRS Archives XXXVIII-8/W3 Workshop Proceedings: Impact of Climate Change on Agriculture.

DeGui, Z., K. FanLing, Z. QunYuan, L. WenXin, Y. FuXin, X. NaiYin, L. Qin and Z. Kui. 2003. Genetic improvement of cotton varieties in the Yangtse valley in China since 1950s. I. Improvement on yield and yield components. Acta Agron. Sinica, 29(2): 208-215.
Hoogenboom, G., Jones, J.W., Wilkens, P.W., Porter, C.H., Boote, K.J., Hunt, L.A., Singh, U., Lizaso, J.L., White, J.W., Uryasev, O., Royce, F.S., Ogoshi, R., Gijsman, A.J., Tsuji, G.Y. and Koo, J. 2012. Decision Support System for Agrotechnology Transfer (DSSAT) Version 4.5. University of Hawaii, Honolulu, Hawaii.

Jones, J.W., Hoogenboom, G., Porter, C.H., Boote, K.J., Batchelor, W.D., Hunt, L.A., Wilkens, P.W., Singh, U., Gijsman, A.J. and Ritchie, J.T. 2003. DSSAT Cropping System Model. Euro. J. Agro., 18: 235-265.

Jost, P.H. and J.T. Cothren. 2000. Growth and yield comparisons of cotton planted in conventional and ultra-narrow row spacing. Crop Sci., 40(2): 430-435.

Ortiz, B.V., Hoogenboom, G., Vellidis, G., Boote, K.,Davis, R.F. and Perry, C. 2009. Adapting the CROPGRO- cotton model to simulate cotton biomass and yield under southern root knot nametodes parasitism. Ameri. Soc. Agril. Bio. Engi., ISSN 2151-0032. 52(6): 2129-2140.

Singh, P., Boote, K.J., Rao, A.Y., Iruthayaraj, Sabani, M.B., Shakh, A.M., Hundal, S.S., Natraj, R.S. and Singh, P. 1994. Evaluation of the groundnut model PNUTGRO for crop response to water availability, sowing dates and seasons. Field Crops Res., 39: 147-162.

Singh, M., Kalra, N., Chakraborty, D. Kamble, K., Barman, D., Saha, S., Mittal, R.B. and Pandey, S. 2008. Biophysical and socioeconomic characterization of a water-stressed area and simulating Agri-production estimates and land use planning under normal and extreme climatic events.

Soler, C.M.T., Sentelhas, P.C. and Hoogenboom, G. 2007. Application of the CSM-CERES-Maize model for planting date evaluation and yield 
forecasting for maize grown off-season in a subtropical environment. Eur. J. Agron., doi:10.1016/ j.eja.2007.03.002.

Tsuji, G.Y., Uehara, G. and Balas, S.(eds.). 1994. DSSAT: a decision support system for agrotechnology transfer. Version 3.Vols. 1, 2 and 3. University of Hawaii, Honolulu, HI.
Uehara, G. and Tsuji, G.Y. 1998. Overview of IBSNAT. In: Tsuji, G.Y., Hoogenboom, G., Thornton, P.K. (Eds.), Understanding Options for Agricultural Production. Kluwer Academic Publishers, Dordrecht, The Netherlands, pp. 1-7.

\section{How to cite this article:}

Sagar Kumar, Ram Niwas, M.L. Khichar, Amit Singh, Premdeep, Yogesh Kumar and Abhilash. 2017. Genetic Coefficient and Validation of DSSAT Model for Cotton under Different Growing Environments. Int.J.Curr.Microbiol.App.Sci. 6(4): 1031-1041. doi: https://doi.org/10.20546/ijcmas.2017.604.128 